\title{
MOORA Optimizasyon Yaklaşımı ile İnşaat Proje Müdürü Seçimi: Çok Kriterli Bir Karar Verme Uygulamas1
}

\author{
Latif Onur UĞUR* \\ Düzce Üniversitesi, Teknoloji Fakültesi, İnşaat Mühendisliği Bölümü, Konuralp/ DÜZCE \\ (Geliş/Received : 16.09.2016 ; Kabul/Accepted : 24.01.2017)
}

ÖZ

Büyük yatırım bedelleri, detaylandırılmış kalite şartları ve sürekli bir baskı oluşturan sınırlı yapım süreleri; inşaat projelerinin detaylı bir şekilde planlanmasını, organize edilmesini ve metodolojik kontrollerini gerektirmektedir. Günümüz ekonomik şartlarında düşük karlarla yüklenilen yapım projeleri için gereken nitelikte proje müdürleri bulmak da başlı başına bir konu haline gelmiştir. Bu çalışmada, yabancı bir ülkede (Rusya) yapılacak büyük bir inşaat projesinin yönetiminde yer alacak bir proje müdürünün seçilmesi amaçlanmıştır. Seçim, çok kriterli karar verme yöntemlerinden MOORA yaklaşımı ile yapılmış; hem Oran Analizi tabanlı hem de Referans Noktası Teorisi esaslı hesaplamalar yapılarak elde edilen sıralamalar karşılaştırılmıştır. MOORA yönteminin temel alındığı böyle bir karar modelinin inşaat firmalarında proje müdürü seçimi ve değerlendirilmesi konularında kullanılabileceği anlaşılmıştır. Uygulanan model, kriterlerin değiştirilmesiyle benzer yapım firmalarında da kullanılabilir.

Anahtar Kelimeler: İnşaat proje müdürü, yönetici seçimi, çok kriterli karar verme, MOORA yöntemi.

\section{Construction Project Maneger Selection With the MOORA Optimisation Method: A Multi-Objective Optimization Application}

\begin{abstract}
Large investment costs, detailed quality requirements and limited construction periods of forming a continuous stress requires; in the planning details, being organized and methodical checks of construction projects. In today's economic conditions, finding project managers which have required quality for the construction projects which incurred with low profits, is a subject itself. In this study, selection of a project manager who will work in big construction project in a foreign country (Russia) aimed. The selection proses made with a multi-criteria approach method, MOORE decision-making process. Ratio Analysis and Reference Point based calculations made and obtained sequences compared. Such a decision model based on the MOORA method, sides may be used for election and evaluation of project managers in construction companies. Application of the model, can be use in similar construction companies by changing the criterias.
\end{abstract}

Keywords: Construction project maneger, manager selection, multi-objective optimization, MOORA method.

\section{GİRIŞ (INTRODUCTION)}

Proje kavramı için yapılmış tanımlardan ikisi; “eşsiz bir ürün ya da hizmeti ortaya çıkartmak için ortaya konulan geçici çaba" ve "değişik alanlarda önceden plan ve programa alınmış, maliyeti hesaplanmış, kurum ve kuruluşların yönetim organları tarafından onaylanmış, kısa ve uzun vadeye bağlanarak özel kurum veya devlet adına gerçekleştirilmesi kabul edilmiş bilimsel çalışma tasarisı"dir (1).

Proje yönetimi, belirli bir projenin hedef ve amaçlarına ulaşıp bitirilmesi için kaynakların planlanması, organize edilmesi, tedarik edilmesi ve yönetilmesi disiplinidir. İnşaat proje yönetimi, sözleşmelerde tarif edilen kalite standartlarından ödün vermeksizin, tasarım öncesinden

*Sorumlu Yazar (Corresponding Author)

e-posta: latifugur@duzce.edu.tr

Digital Object Identifier (DOI) : başlayarak projenin tesliminden sonraki anahtar teslimine kadar geçen etapların tamamının veya belli bir kısmının planlanmasının mal sahibi adına temsilci sıfatıyla yönetilmesi hizmetlerinin adıdır. Proje yöneticisi, proje boyunca sadece kilit öneme sahip kararları müşteriye bırakarak müşteri adına hareket eden dışarıdan temin edilen bir yönetici gibi hareket eder (2).

İnşaat projelerinde proje müdürlerinin Görev Yetki ve Sorumlulukları aşağıdaki gibi sıralanabilir (3) :

- Üst yönetim tarafından belirlenen proje yönetim politikaları ve buna bağlı oluşturulan sistemlerin, projeye bağlı şantiye veya şantiyeler tarafından anlaşılmalarını ve faaliyetlerin bu çerçevesinde yürütülmesinin sağlanması.

- Kendisine bağlı olan Proje veya Projelerin Master plan, bütçe ve iş programlarının hazırlanması 
gerektikçe revize edilmesi, bunların gerçekleşmelerinin takibi ve projenin bağlı olduğu gurup direktörüne raporlanması. Hazırlanan raporlara bağlı olarak iş gücü, finansman ihtiyacı ve proje sonu projeksiyon tahminleriyle projelerin yapımı sırasında olası aksaklıklarını tespit ederek gerekli önlemlerin önceden alınmasını sağlamak.

- Mobilizasyon öncesinde veya mobilizasyon süresince "Proje Yönetim Planı"nın hazırlanması ve projenin bu plan dahilinde yürütülmesi.

- Proje Organizasyonunun oluşturulması, malzeme, makina/ekipman techizat ve personel programlarının hazırlanarak bunların temini ve proje boyunca en verimli biçimde kullanımının sağlanmas1.

- Projede kullanılacak taşeronların seçilmesi, onaylanması, taşeron sözleşmelerinin hazırlanarak imzalanması, taşeronun yönetim ve idaresi, taşeron performanslarının takibinin ilgili prosedürlere uygun olarak yürütülmesi.

- Malzeme tedarikçilerinin seçilmesi, onaylanması, yetki sınırları içerisinde tekliflerin değerlendirilerek uygun tedarikçilerin belirlenmesi, malzeme temin sözleşmelerinin hazırlanması, tedarikçilerin performanslarının takibi.

- Proje faaliyetlerinin düzenli ve hızlı biçimde yürütülmesini sağlamak için Proje ile Merkez birimler arasındaki iletişim ve koordinasyonun etkin biçimde kurulması.

- Proje ile merkez arasında tanımlanan Proje bilgi akışının ( muhasebe ve bordro bilgileri, iş ilerleme raporları vb.) sağlanması.

- Proje nakit akışının planlanarak ihtiyacın veya fazlanın tespit edilerek merkez'e bildirilmesi.

- Şantiye'de gerçekleştirilen hizmet ve imalatlara ilişkin hakediş ve kesin hesapların zamanında ve sözleşmeye ve şirket çıkarlarına uygun ve doğru olarak şirket çıkarlarına uygun olarak hazırlanmasının sağlanması, kontrolu, İşveren'e onaylatılması.

- Ambar, muhasebe, personel, kamp, üretim tesisleri, makina parkı, atölye ve yardımcı tesisler gibi tüm şantiye hizmet ve destek birimlerinin işin akışına uygun ve birbirleriyle ve merkez birimlerle uyumlu biçimde çalışmalarının sağlanmasi.

- İş güvenliğinin ilgili yönetmelik ve prosedürlere uygun olarak sağlanması için her türlü önlemin alınması, faaliyetlerin denetlenmesi.
- İşveren ve İşveren temsilcileriyle, ortaklarla iyi ilişkilerin kurulmasını ve sürdürülmesinin sağlanmasi.

- Şantiye çalışanları, sendika temsilcileri, resmi kuruluşlarla ve genel olarak çevre halkıyla iyi ilişskiler geliştirerek şirketin en iyi biçimde temsil edilmesi.

- Mobilizasyon ve demobilizasyon faaliyetlerinin planlanması, yönetilmesi ve sonuçlandırılması.

- Geçici kabul, kesin kabul gibi Proje teslimine yönelik tüm çalışmalarının İşveren/İşveren temsilcisi ve Merkez birimlerle yürütülmesi, koordinasyonu ve sonuçlandırılması.

- Tüm Şantiye faaliyetlerinin kalite standartlarına ve bu standartlara göre oluşturulan prosedür ve diğer dökümanlara uygun olarak gerçekleştirilmesinin sağlanması.

- Mukavele tatbikatı çalışmalarının İşveren/İşveren temsilcisine karşı yürütülmesi ve koordinasyonu. Yurtiçi ve yurtdışı teknik müşavir, hukukçularla işbirliği içinde anlaşmazlıkların ve taleplerin çözümünde etkin rol alınması.

Anılan nitelikte sorumlulukların hakkıyla yerine getirilebilmesi için proje müdürü adaylarının sahip olması gereken pek çok nitelikten birkaçı; eğitim, liderlik, iletişim yeteneği, pragmatik olmak, organize edicilik, ileri görüşlülük, dürüst ve çözüm odaklı olmaktır.

Büyük yatırım bedelleri, detaylandırılmış kalite şartları ve sürekli bir baskı oluşturan sınırlı yapım süreleri; inşaat projelerinin detaylı bir şekilde planlanmasını, organize edilmesini ve metodolojik kontrollerini gerektirmektedir. Tüm bu işlerden birinci derecede sorumlu olacak proje müdürlerine ise büyük yükler düşmekte ve ağır sorumluluklar yüklenmektedir. Günümüz ekonomik şartlarında düşük karlarla yüklenilen yapım projeleri için gereken nitelikte proje müdürleri bulmak da başlı başına bir konu haline gelmiştir. Personel ilanları ve güvenilir referanslar her kendine özgü yapım projesinin idarecisinin seçiminde temel bir fayda sağlamaktadır. Ancak elemeler sonucunda kalan az sayıda nitelikli adaylardan birinin seçilmesi konusunda pek çok farklı özelliği olan adaylardan, o projeye has gerekli nitelikleri maksimize eden birinin seçilmesi, daha projenin başında verilecek hayati bir karar mahiyetindedir.

"Bir iş veya sorun hakkında düşünülerek verilen kesin yargıya" ya da "Herhangi bir durum için tartışılarak verilen kesin yargiya" karar denmektedir (4). Hedef ve amaçların gerçekleştirilmesi yönünde mevcut alternatifler arasından birini seçme eylemi de karar kavramı için kullanılan tanımlardan biridir. Karar verme günümüzde, birçok bilim alanı ile arakesiti olan geniş kapsamlı bir bilim dalı olmuştur (5). 
Nicel değişkenlerin yanında nitel değişkenleri de ölçmek gerekliliğinden dolayı karar verilecek ortamın çok iyi analiz edilmesi gerekmektedir. Bu da çok fazla veriye sahip olmayı ve sayısal teknikleri kullanmayı bir ihtiyaç haline getirmiştir (6). Günümüzde zorlaşan ve karmaşıklaşan karar süreçlerinin karar vericinin bireysel becerileri yanında daha verimli, hızlı karar almasına olanak sağlayacak karar verme araçları ile desteklenmesi gerekmektedir (7). Rasyonel karar almak için tecrübeler, sezgiler ve sınırlı bilgilerin yanı sıra karar sürecinin analitik olarak da değerlendirilmesi gerekmektedir (8).

Karar verme sürecinin aşamaları; Amaç belirleme ve sorunu tanımlama, Amaç ve sorunları irdeleme, Öncelik belirleme, Alternatif belirleme, Alternatifleri irdeleme ve değerleme, Seçim kriterlerini belirleme ve Seçim yapmadır (9). Herhangi bir karar için gerekli olan elemanlar ise; Karar verici, Amaç, Karar kriterleri, Seçenekler, Olaylar ve Sonuçtur (10)

Çok Kriterli Karar Verme; matematik, yönetim, enformatik psikoloji, sosyal bilimler ve ekonomi gibi birden çok disiplinin bir araya gelip karar alıcıya birden fazla boyutla karar problemini değerlendirme ve karar alma imkanı sağlayan yöntemlerin bir araya getirildiği yapıdır. Çok Kriterli Karar Verme Problemleri; birden fazla kriterin optimize edildiği mümkün çözüm setleri içerisinden en iyi alternatifin seçildiği problemler olarak tanımlanabilir (10). Çok Kriterli Karar Verme Problemleri üç temel başlık altında incelenebilir; Seçim, Sınıflama ve Sıralama (11).

Bir işletmenin insan kaynakları yönetiminde en önemli ve en zor konuyu işgören bulma ve seçme teknikleri oluşturur (12). Her alanda ihtiyaç duyulan personel seçimi ve alımı, kurumun/kuruluşun amaçları ve hedefi doğrultusunda temel ve tartışmasız çok önemli bir konudur. Doğru anlaşılması, uygun metodların seçilmesi ve uygulanması durumunda kurumun/kuruluşun stratejik amaçları ve beklentilerine ulaşması için büyük bir öneme sahiptir (13).

Özbek, kuruluşlarda en uygun adayın belirlenmesinin çok kriterli karar verme problemi olarak görüldüğünü ifade etmektedir. Araştırmasında Bulanık Analitik Hiyerarşi Süreci yöntemini temel alan bir yönetici belirleme modeli geliştirmiştir. Bu yöntem, adayların değerlendirilme sürecinde kesin olmayan ve belirsiz verilerin kullanılması yanında nitel ve nicel kriterleri de değerlendirme sürecine katabilen bir yöntemdir. Önerilen model, yedi adayı, on iki kritere göre değerlendirmiş ve uygulamanın yapıldığı kuruluş için en uygun adayı belirlemiştir (14). Öngörmüş ve diğ., bir işletmedeki personel seçim problemini ele almıştır. Çalışmalarında personel seçiminde, işletme için önemli olan nitel ve nicel kriterler belirlenerek, niteliksel ve niceliksel değişkenlerin değerlendirilmesinde etkili bir yöntem olan Analitik Hiyerarşi Prosesi (AHP) kullanılmıştır. Kriterlerin ve alternatiflerin değerlendirilmesinde, dilsel değişkenler ve bulanık sayılar kullanılmıştır. Tasarlanan sistemde sonuçlar; bu yöntemin personel seçimine sayısal bir çözüm getirerek karar ver- mede gözle görülebilir bir kolaylık sağladığını göstermiştir (15). Dağdeviren, Bulanık Analitik Hiyerarşi Prosesi yöntemi ile personel seçimi probleminin çözümüne yönelik bir algoritma önermiştir (16). Doğan ve Önder, insan kaynakları temin ve seçim sürecinde çok kriterli karar verme tekniklerini kullanarak, en uygun adayın/adayların seçilebileceği bir modeli ortaya koymak amacı ile; Analitik Hiyerarşi Prosesi (AHP) kullanmışlardır. Bu yaklaşımın karmaşık karar problemlerinin analizinde yaygın olarak kullanılabileceğini ifade eden yazarlar, yaklaşımın alternatiflerin sıralanmasında ve en uygun alternatifin seçiminde karar vericilere yardımcı olması için kullanılabileceğini belirtmişlerdir (17). Tepe ve Görener' in çalışmalarında, Türkiye'deki kurumsal bir şirketin personel seçim süreci ele alınmış; değerlendirmede dikkate alınacak ölçüt ağırlıkları Analitik Hiyerarşi Süreci (AHS) ile hesaplanmış, sonrasında MOORA yöntemini kullanarak personel seçimini gerçekleştirilmiştir (18). Özbek, bir modelde Analitik Hiyerarşi Süreci ve MOORA yöntemlerini bütünleşik olarak kullanmıştır. Yönetici ölçüt ağırlıkları AHS ile belirlenmiş ve en uygun yöneticinin seçimini ise MOORA-MULTIMOORA yöntemine göre yapıştır. Çalışma sonuçları MOORA yönteminin çeşitli sürümlerinde birbirine benzer sonuçlara ulaşıldığını göstermiştir (19).

Bu çalışmada, yabancı bir ülkede (Rusya) yapılacak büyük bir inşaat projesinin yönetiminde yer alacak bir proje müdürünün seçilmesi amaçlanmıştır. Sıralama ve seçim, çok kriterli karar verme yöntemlerinden MOORA yaklaşımı ile yapılmış; hem Oran Analizi tabanlı hem de Referans Noktası Teorisi esaslı hesaplamalar yapılarak elde edilen sıralamalar karşılaştırılmıştır.

\section{MOORA ORAN ANALIZİ TABANLI COK ÖL- ÇÜTLÜ/ NITELIIKLI OPTIMIZASYON YÖN- TEMI (MOORE RATIO ANALYSIS BASED MULTICRITERIA/ QUALITY OPTIMIZATION METHOD)}

MOORA (Multi-Objective Optimization on the basis of Ratio Analysis) yöntemi çok ölçütlü ya da çok nitelikli iki veya daha fazla çakışan niteliği veya amacı belirli kısıtlar altında eş zamanlı olarak optimize etme sürecidir. MOORA yöntemi çeşitli nitelikler ya da amaçlara ilişkin farklı alternatiflerin performansını gösteren Eşitlik 1 'deki karar matrisi ile başlar $(20,21)$.

$$
X=\left[\begin{array}{ccccc}
x_{11} & x_{12} & \ldots & \ldots & x_{1 n} \\
x_{21} & x_{22} & \ldots & \ldots & x_{2 n} \\
\ldots & \ldots & \ldots & \ldots & \ldots \\
\ldots & \ldots & \ldots & \ldots & \ldots \\
x_{m 1} & x_{m 2} & \ldots & \ldots & x_{m n}
\end{array}\right]
$$


Bu karar matrisinde,

$\mathrm{i}=$ alternatif

$\mathrm{j}=$ nitelik yada ölçüt

$\mathrm{m}=$ toplam alternatif sayıs1

$\mathrm{n}=$ toplam nitelik yada ölçüt sayısı

xij=i. Alternatifin j. ölçüt açısından performans ölçüm değeri olarak ifade edilmektedir.

Daha sonra, normalizasyon işlemi gerçekleştirilir. Normalizasyon için kullanılan yöntemler Eşitlik 2'de gösterilen vektör normalizasyonu ve Eşitlik 3'te sunulan doğrusal normalizasyondur (22).

$$
\begin{aligned}
& r_{i j}=\frac{x_{i j}}{\sqrt{\sum_{i=1}^{m} x_{i j}^{2}}}, i=1,2, \ldots, m ; j=1,2, \ldots, n . \\
& r_{i j}=\frac{x_{i j}}{\sum_{i=1}^{m} x_{i j}}, i=1,2, \ldots, m ; j=1,2, \ldots, n .
\end{aligned}
$$

Bu işlem xij ile gösterilen $i$. Alternatifin $j$. ölçüt açısından performans ölçüm değerini verir. Buradaki xij değeri $j$ Ölçüt yada nitelik açısından $i$. Alternatifin normalize edilmiş performansını temsil eden [0,1] aralığında yer alan birimi bulunmayan bir sayıdır. Çok amaçlı optimizasyon için, bu normalize edilmiş performans değerleri (faydalı nitelikler için) maksimizasyon durumunda eklenip, (faydasız nitelikler için) minimizasyon durumunda çıkarılarak her bir alternatif için tek bir değer bulunur. Bu durumda optimizasyon problemi 4 numaralı denklemdeki gibi oluşur (22).

$$
y_{i}=\sum_{j=1}^{g} x_{i j}^{*}-\sum_{j=g+1}^{n} x_{i j}^{*}
$$

Bu eşitlikte, $\mathrm{n}=$ enbüyüklenecek nitelik ya da ölçüt sayısı n-g = enküçüklenecek nitelik ya da ölçüt sayısı yi= tüm nitelik ya da ölçütler açısından i. Alternatife ilişkin normalize edilmiş değerdir.

\section{REFERANS NOKTASI TEORISII (REFERENCE POINT THEORY)}

Referans noktası yaklaşımında, oran metoduna ek olarak her kriter için; amaç maksimizasyon ise maksimum noktalar, amaç minimizasyon ise minimum olan, referans noktaları ( $\mathrm{r}_{\mathrm{j}}$ 'ler) belirlenir. Belirlenen bu noktaların, her $x_{i j}^{*}$ ile olan uzaklıkları bulunur. Yani;

$\mathrm{r}_{\mathrm{j}}-x_{i j}^{*}$

işlemi yapılır ve matris olarak yazılır. Burada;

$\mathrm{i}=1,2, \ldots, \mathrm{m}$ alternatiflerin sayısını,

$\mathrm{j}=1,2, \ldots, \mathrm{n}$ kriterlerin sayısını,

$x_{i j}^{*}, i$. alternatifin $j$. kriterdeki normalleştirilmiş değerini,

$\mathrm{r}_{\mathrm{j}}, j$. kriterin referans noktasını göstermektedir.
Oluşturulan matrise Eşitlik 6. 'da gösterilen "Tchebycheff Min-Maks Metrik İşlemi” uygulanır

$P_{i}=\operatorname{Min}_{i}\left(\operatorname{Max}_{j}\left|r_{i} x_{i j}^{*}\right|\right)$

Böylece sıralama yapılır $(23,24,25)$.

\section{UYGULAMA (APPLICATION)}

Yurtdışında yapılacak büyük bir inşaat projesinin ihalesini alan yapım firması, bu proje için bir proje müdürü seçecektir. Adayların belirlenmesi için internet ve yazılı basın üzerinden, bu görevin gerektirdiği çok sayıda niteliği içeren iş ilanları verilmiş, sektör profesyonellerinden öneriler istenmiş ve olabildiğince fazla adayın başvuru yapması için çaba harcanmıştır. Ön değerlendirme ve yüzyüze görüşme aşamalarının ardından projeye en uygun beş aday nihai değerlendirmeye alınmıştır. Yapılacak bir sıralama ve seçim çalışması için MOORA yöntemi kullanılmasına karar verilmiş; hem Oran Analizi tabanlı hem de Referans Noktası Teorisi esaslı hesaplamalar yapılarak elde edilen sıralamalar değerlendirilmiş ve seçim yapılmıştır. Adayların değerlendirilmesindeki temel kriterler firma yöneticileri ve insan kaynakları bölümü elemanları görüşleri esas alınarak aşağıdaki gibi oluşturulmuştur;

K1: Mezun olunan okul: Alınan teknik eğitimin ve bilgi temelinin kalitesine referans olması için adayların mezun oldukları okullar ve bölümler firma teknik ve idari yöneticileri tarafından beşli Ricat Ölçeği kullanılarak puanlandırılmıştır. En yüksek puanlar, daha iyi teknik altyapıyı ifade etmektedir.

K2: Aktif mühendislik süresi: Mezun olunduktan sonra fiilen yapılan çalışma süreleridir, adayların başvuru formlarından edinilmiş bilgiler yine adaylarca görüşülüp revize edilerek veri oluşturulmuştur. Aktif mühendislik süresi en çok olan aday bu kritere göre en olumlu seçenek kabul edilmiştir.

K3: Yaş: Fiilen çok enerji sarf etmesi gerekecek adayların bu kritere göre en genç olanı avantajlı olacaktır.

K4: Tamamlanan proje sayısı: İnşaat sektöründe sık iş değiştirmelerin doğal olduğu ve bunların bir kısmının projeler tamamlanmadan önce gerçekleștiği göz önüne alınarak, çalışılan işlerin tamamlanması aşamasına kadar görev yapmış (sebat göstermiş, vazgeçilmemiş) olmak da başka bir tercih sebebi olarak firma yönetimince kriterler arasına alınmıştır. Bu kriterde ne kadar çok proje tamamlandı ise o kadar tercih sebebi olunacaktır.

K5: Yabancı dil: Yurtdışında ve kamuya yapılacak bir projenin sözkonusu olması yabancı dili akıcı olarak kullanma ve teknik terimlere hakim olma niteliğini gerektirecektir. Önce İngilizce, ardından Rusça bilmek, beşli Ricat Ölçeği ile puanlandırılmış ve adayların yabancı dil kriter puanları oluşturulmuştur. Puanı yüksek olan adayın daha iyi yabancı dil hakimiyeti olduğu kabul edilmiştir.

K6: Referanslar: İnşaat sektöründe daha önce çalışılan firmalarda ve projelerde görev yapmış önemli kademedeki kimselerin referansları büyük önem arz etmektedir. Gerek firmanın insan kaynakları elemanları gerekse proje 
ile ilgili teknik ve idari personelce yapılan referans araştırmaları sonucunda her aday için 10 üzerinden puanlandırma yapılmıştır. Puanı yüksek olmak, tercih sebebi olarak alınmıştır.

K7: İletişim yeteneği: Gerek insan kaynakları elemanlarının gerek proje genel koordinatörünün yaptığı değerlendirmeler esas alınarak, referansların ifadeleri de gözönünde bulundurularak, 10 puan üzerinden iletişim yeteneği değerlendirmesi yapılmıştır. Puanı yüksek olan daha iyi iletişim yeteneğine sahip kabul edilmiştir.

K8: Talep edilen ücret: Her bir adaya talep ettiği net aylık ücret sorulmuş, verdikleri yanıtlardaki değerler aynen alınarak değerlendirme kriteri olarak kullanılmıştır. Adaylar ne kadar düşük ücret isterlerse o kadar tercih edileceklerdir.

Kriterlerin yukarıdaki kapsamla belirlenmesi ile kesin olmayan ve belirsiz verilerin kullanılması yanında nitel ve nicel kriterleri de değerlendirmek mümkün olmuştur. Değerlendirme esaslarına göre; kriterlerden altı tanesinde en yüksek puan alınması tercih sebebiyken iki tanesinde de en düşük puan almak tercih sebebi olacaktır. Kriterlerin her biri eşit ağırlıkta değerlendirilmiştir. Bu verilere göre; adayların, kriterlerin ve her adayın hangi kritere göre kaç puan aldığının değerleri Çizelge 1.'de verilmiştir.
Çizelge 1.'de verilen değerler (2) ifadesi kullanılarak normalize edilmiştir. Bu işlemin sonucunda elde edilen değerler Çizelge 2.'deki gibidir. Ayrıca bu Çizelgede maksimum ve minimum olması istenen kriterler de belirtilmiştir

Çizelge 2.'deki değerler kullanılarak (4) formülü yardımı ile $\mathrm{y}_{\mathrm{i}}{ }^{*}$ değeri hesaplanmış ve Oran Metodu'na göre sıralama yapılmıştır. Çizelge 3. Bu hesabın sonuçlarını göstermektedir.

Çizelge 3. Oran Metodu'na göre siralama (Rate sort by Unit Credit Method)

\begin{tabular}{|l|c|c|}
\hline & yi* & $\begin{array}{c}\text { Oran Metodu } \\
\text { Siralama }\end{array}$ \\
\hline Aday 1 & 2,040529077 & 1 \\
\hline Aday 2 & 1,426417935 & 5 \\
\hline Aday 3 & 1,861930952 & 2 \\
\hline Aday 4 & 1,598929562 & 4 \\
\hline Aday 5 & 1,82863978 & 3 \\
\hline
\end{tabular}

Referans Noktası Yaklaşımı kullanılarak sıralama yapmak için Çizelge 2.'deki değerlerden referans noktalar belirlenmiştir. Bu değerler Çizelge 4.'ün en alt satırında verilmiştir.

Çizelge 1. Sıralanacak adaylar ve bu adaylara ait kriterlerin değerleri (Candidates will be listed and the value of the criteria of these candidates)

\begin{tabular}{|l|c|c|c|c|c|c|c|c|}
\hline & K1 & K2 & K3 & K4 & K5 & K6 & K7 & K8 \\
\cline { 2 - 10 } & $\begin{array}{c}\text { Mezun olunan } \\
\text { okul }\end{array}$ & $\begin{array}{c}\text { Aktif } \\
\text { mühendislik }\end{array}$ & Yaş & $\begin{array}{c}\text { Tamamlanan } \\
\text { proje sayıs }\end{array}$ & Yabanc1 dil & Referanslar & $\begin{array}{c}\text { İletişim } \\
\text { yeteneği }\end{array}$ & $\begin{array}{c}\text { Talep ettĭg } \\
\text { ücret }\end{array}$ \\
\hline Aday 1 & 5 & 27 & 52 & 8 & 5 & 8 & 7 & 6200 \\
\hline Aday 2 & 4 & 22 & 51 & 5 & 4 & 7 & 5 & 5500 \\
\hline Aday 3 & 5 & 18 & 45 & 5 & 5 & 9 & 9 & 7000 \\
\hline Aday 4 & 3 & 24 & 54 & 9 & 3 & 7 & 8 & 6500 \\
\hline Aday 5 & 5 & 25 & 49 & 7 & 4 & 6 & 7 & 5000 \\
\hline
\end{tabular}

Çizelge 2. Normalizasyon işlemi sonucunda elde edilen değerler (The values obtained as a result of normalization process)

\begin{tabular}{|c|c|c|c|c|c|c|c|c|}
\hline & MAKS & MAKS & MIN & MAKS & MAKS & MAKS & MAKS & MIN \\
\hline & K1 & $\mathrm{K} 2$ & K3 & K4 & K5 & K6 & K7 & K8 \\
\hline Aday 1 & 0,5 & 51599684 & 0,462391 & 0,51214752 & 0,52414242 & 0,47894747 & 0,42759306 & 0,455907003 \\
\hline Aday 2 & 0,4 & 0,42044187 & 0,453499 & 0,3200922 & 0,41931393 & 0,41907904 & 0,30542361 & 0,404433631 \\
\hline Aday 3 & 0,5 & 0,34399789 & 0,400146 & 0,3200922 & 0,52414242 & 0,53881591 & 0,5497625 & 0,514733713 \\
\hline Aday 4 & 0,3 & 0,45866386 & 0,480176 & 0,57616596 & 0,31448545 & 0,41907904 & 0,48867778 & 0,477967019 \\
\hline Aday 5 & 0,5 & 0,47777485 & 0,435715 & 0,44812908 & 0,41931393 & 0,3592106 & 0,42759306 & 0,367666938 \\
\hline
\end{tabular}

Çizelge 4. Referans noktalarının hesabı (Calculation of the reference point)

\begin{tabular}{|c|c|c|c|c|c|c|c|c|}
\hline & $\mathrm{K} 1$ & $\mathrm{~K} 2$ & $\mathrm{~K} 3$ & $\mathrm{~K} 4$ & $\mathrm{~K} 5$ & $\mathrm{~K} 6$ & $\mathrm{~K} 7$ & $\mathrm{~K} 8$ \\
\cline { 2 - 9 } & 0,5 & 0,51599684 & 0,462391 & 0,51214752 & 0,52414242 & 0,47894747 & 0,42759306 & 0,455907003 \\
\hline Aday 1 & 0,4 & 0,42044187 & 0,453499 & 0,3200922 & 0,41931393 & 0,41907904 & 0,30542361 & 0,404433631 \\
\hline Aday 2 & 0,5 & 0,343997894 & 0,400146 & 0,3200922 & 0,52414242 & 0,53881591 & 0,5497625 & 0,514733713 \\
\hline Aday 3 & 0,3 & 0,458663858 & 0,480176 & 0,57616596 & 0,31448545 & 0,41907904 & 0,48867778 & 0,477967019 \\
\hline Aday 4 & 0,5 & 0,477774852 & 0,435715 & 0,44812908 & 0,41931393 & 0,3592106 & 0,42759306 & 0,367666938 \\
\hline Aday 5 & 0,5 & 0,51599684 & 0,400146 & 0,57616596 & 0,52414242 & 0,53881591 & 0,5497625 & 0,367666938 \\
\hline $\begin{array}{l}\text { Referans } \\
\text { Noktalar1 }\end{array}$ & & & & & & & & \\
\hline
\end{tabular}


$\mathrm{Bu}$ değerlerle (6) ifadesi uygulanarak hesaplamalar yapılmıştır. Bu hesap değerleri Çizelge 5.’te verilmiştir.
MOORA yönteminin temel alındığı karar modelinin inşaat firmalarında proje müdürü seçimi ve

Çizelge 5. (6). ifadesinin kullanımı ile yapılan hesaplamalar (Calculations with the use of the term (6.))

\begin{tabular}{|c|c|c|c|c|c|c|c|c|}
\hline & $\mathrm{K} 1$ & $\mathrm{~K} 2$ & $\mathrm{~K} 3$ & $\mathrm{~K} 4$ & $\mathrm{~K} 5$ & $\mathrm{~K} 6$ & $\mathrm{~K} 7$ & $\mathrm{~K} 8$ \\
\hline & 0 & 0 & 0,062245 & 0,06401844 & 0 & 0,05986843 & 0,12216944 & 0,088240065 \\
\hline Aday 1 & 0,1 & 0,09555497 & 0,053353 & 0,25607376 & 0,10482848 & 0,11973687 & 0,24433889 & 0,036766694 \\
\hline Aday 2 & 0 & 0,171998947 & 0 & 0,25607376 & 0 & 0 & 0 & 0,147066775 \\
\hline Aday 3 & 0,2 & 0,057332982 & 0,080029 & 0 & 0,20965697 & 0,11973687 & 0,06108472 & 0,110300081 \\
\hline Aday 4 & 0 & 0,038221988 & 0,035569 & 0,12803688 & 0,10482848 & 0,1796053 & 0,12216944 & 0 \\
\hline Aday 5 & & &
\end{tabular}

Elde edilen verilerin maksimum değerleri ve Referans Noktası Teorisi'ne göre yapılan sıralama Çizelge 6.'da verilmiştir.

Çizelge 6. Referans Noktası Yaklaşımı'na göre sıralama (Sort according to Reference Point Approach)

\begin{tabular}{|c|c|c|}
\hline & $\begin{array}{c}\text { Maksimum } \\
\text { değerler }\end{array}$ & Siralama \\
\cline { 2 - 3 } & 0,122169444 & 1 \\
\hline Aday 1 & 0,25607376 & 4 \\
\hline Aday 2 & 0,25607376 & 4 \\
\hline Aday 3 & 0,209656967 & 3 \\
\hline Aday 4 & 0,20965302 & 2 \\
\hline Aday 5 & 0,179605302 \\
\hline
\end{tabular}

Böylece MOORA Yöntemi'nin iki farklı yaklaşımına göre sıralama yapılmıştır. Her iki yaklaşıma göre de "Aday 1" en uygun seçenek olarak belirlenmiştir. Oran Yöntemi'ne göre ikinci surada yer alan "Aday 3", Referans Noktası Yaklaşımı'na göre dördüncü sırada yer alırken; Oran Yöntemi'ne göre üçüncü sırada yer alan “Aday 5", Referans Noktası Yaklaşımı'nda ikinci sırayı almıştır. Sonuçta iki yaklaşımda da ilk sırayı alan aday söz konusu yapım projesi için proje müdürü olarak tercih edilmiştir.

\section{SONUÇ (RESULTS)}

Ayrık alternatiflerle çok amaçlı optimizasyon için önerilen yöntemlerden biri olan MOORA Yöntemi, önemliliği verilmiş amaç durumunda da başarı ile kullanılan bir yöntemdir. Yöntemin diğer çok kriterli karar verme yöntemleri olan Analitik Hiyerarşi Süreci (AHP), Analitik Ağ Süreci (ANP), VIKOR, TOPSİS, ELECTRE, PROMETHEE, MACBETH, UTA, STEM ve PAPRIKA gibi yöntemlerle birlikte ya da hibrit olarak kullanılması mümkün görülmektedir.

Seçim kriterlerinin belirlenmesi esnasında kesin olmayan ve belirsiz verilerin kullanılması yanında nitel ve nicel kriterleri de değerlendirmek mümkün olmuştur. Dolayısı ile MOORA yaklaşımında nitel ve nicel kriterler bir arada kullanılabilmiştir. Bu yöntemin kullanımı ile proje müdürü seçimine sayısal bir çözüm getirilerek karar vermede önemli bir kolaylık sağlanmıştır.

Modelin uygulanması için özel yazılım programlarına ihtiyaç duyulmamaktadır. Tüm hesaplamalar elektronik tablolama programı ile gerçekleştirebilmektedir. değerlendirilmesi konularında kullanılabileceği anlaşılmıştır. Uygulanan model, kriterlerin değiştirilmesiyle benzer yapım firmalarında da kullanılabilir. Farklı kuruluşlarda kriterlerin değerlendirilmesi farklı uzmanların değer yargılarına göre yapılacağından farklı sonuçların bulunması da olasidir

\section{KAYNAKLAR}

1. TDK Büyük Türkçe Sözlük, Son erişim tarihi: 13.09.2016

http://www.tdk.gov.tr/index.php?option=com_bts\&aram $\underline{\text { a=kelime \& guid=TDK.GTS.57d7adc8484798.10803611 }}$

2. http://mgamimarlik.com.tr/mgamimarlik.com.tr/tr/insaat -proje-yonetimi-nedir-ne-faydasi-var/index.html Son erişim tarihi: (13.09.2016)

3. http://www.bedavahizmet.com/faydali_bilgi.aspx?ID=5 14\&baslik=Santiye_personelinin_gorev_tanimlariSon erişim tarihi:(13.09.2016)

4. Türk Dil Kurumu, Büyük Türkçe Sözlük, son erişim tarihi $(02.09 .2016)$ http://www.tdk.gov.tr/index.php?option=com_bts\&aram $\mathrm{a}=$ kelime\&guid=TDK.GTS.57c94dc09aa9a2.86045855

5. Esen Ö., "Önsöz”, Çok Kriterli Karar Verme Yöntemleri, Dora Yayınevi, iii, Bursa, (2015).

6. Özdemir E., "Önsöz”, Çok Kriterli Karar Verme Yöntemleri, Dora Yayınevi, vii, Bursa, (2015).

7. Yıldırım B.F. ve Önder E., "Takdim”, Çok Kriterli Karar Verme Yöntemleri, Dora Yayınevi, ix, Bursa, (2015).

8. Can M., "Karar Teorisi”, Çok Kriterli Karar Verme Yöntemleri, Dora Yayınevi, 1, Bursa, (2015).

9. Koçel T., "İşletme yöneticiliğì", Beta Basım Yayım Dağıtım A.Ş., (2001).

10. Turan G., "Lagrange gevşetmesi ile küçük portföylerin elde edilmesi ve İMKB'ye uygulanması”, Doktora Tezi, (2013).

11. Vassilev V., Genova K. and M. Vassileva, "A brief survey of multicriteria decision making methods", Bulgarian Academy of Sciences Cybernetics and Information Tedchnologies, 5(1): 4, (2005).

12. Sabuncuoğlu, Z., “İnsan kaynakları yönetimi”, 72, Bursa: Ezgi Yayınları, (2000). 
13. Altun A. ve Kovac1 A., "Personel seçiminde mülakat ve mülakat yöntemleri”, Havacılık ve Uzay Teknolojileri Dergisi, 1(3): 55-61, (2004).

14. Özbek A., "Yöneticilerin çok kriterli karar verme yöntemi ile belirlenmesi", Yönetim ve Ekonomi Araştırmaları Dergisi, 24, (2014).

15. Özgörmüş E., Mutlu Ö. ve Güner H., "Bulanık AHP ile personel seçimi”, V. Ulusal Üretim Araştırmaları Sempozyumu : Düşünceden Uygulamaya Değer Yaratma, İstanbul, 14, (2005).

16. Dağdeviren M., "Bulanık analitik hiyerarşi prosesi ile personel seçimi ve bir uygulama", Gazi Üniversitesi Mühendislik Mimarlık Fakültesi Dergisi, 22(4): (2007).

17. Doğan A. ve Önder E., "İnsan kaynakları temin ve seçiminde çok kriterli karar verme tekniklerinin kullanılmas1 ve bir uygulama" Journal of Yasar University, 9(34): 5796-5819, (2014).

18. Tepe S. ve Görener A., "Analitik hiyerarşi süreci ve moora yöntemlerinin personel seçiminde uygulanması", İstanbul Ticaret Üniversitesi Fen Bilimleri Dergisi Y11: 13(25): 1-14, (2014).

19. Özbek A., "Akademik birim yöneticilerinin moora yöntemiyle seçilmesi: Kırıkkale üzerine bir uygulama", Kırıkkale Üniversitesi Sosyal Bilimler Enstitüsü Dergisi 38(1): 1-18, (2015).
20. Brauers W. K. M., Ginevic `ius R. and Podvezko V., "Regional development in Lithuania considering multiple objectives by the MOORA method", Technol Econ Dev Econ, 16: 613-640, (2010).

21. Chakraborty S., "Applications of the MOORA method for decision making in manufacturing environment". Int J Adv Manuf Technol, 54: 1155-1166, (2011).

22. Özdağoğlu A., "Normalizasyon yöntemlerinin çok ölçütlü karar verme sürecine etkisi-Moora yöntemi incelemesi”, Ege Akademik Bakış, 14(2): 283-294, (2014).

23. Brauers W. K. M., Zavadskas E. K., "The MOORA method and its application to privatization in a transition economy", Control and Cybernetics, 35(2): 445-469, (2006).

24. Brauers W. K. M. and Ginevicius R., "Robustness in regional develeopment studies: the case of Lithuania", Journal of Business Economics and Management, 10(2): 121-140, (2009).

25. Brauers W. K. M. and Ginevicius R., "The economy of the belgian regions tested with MULTIMOORA", Journal of Business Economics and Management, 11(2), 173-209, (2010). 